\title{
Histology Cassette
}

National Cancer Institute

\section{Source}

National Cancer Institute. Histology Cassette. NCI Thesaurus. Code C128638.

A device designed to hold tissue specimens during processing, embedding and storage. 